\title{
HOW NEANDERTHALS GRIPPED RETOUCHERS: EXPERIMENTAL RECONSTRUCTION OF THE MANIPULATION OF BONE RETOUCHERS BY NEANDERTHAL STONE KNAPPERS
}

\author{
Kseniya Kolobova ${ }^{1}$ Vladimir Kharevich ${ }^{1}$ • Pavel Chistyakov ${ }^{1}$ Anastasiya Kolyasnikova ${ }^{1}$ Aliona Kharevich ${ }^{1}$ • \\ Malvina Baumann ${ }^{1} \cdot$ Sergey Markin ${ }^{1} \cdot$ John W. Olsen ${ }^{1} \cdot$ Andrey Krivoshapkin ${ }^{1}$ \\ ${ }^{1}$ Institute of Archaeology and Ethnography, Russian Academy of Sciences Siberian Branch, Novosibirsk 630090, \\ Russia \\ ${ }^{2}$ Liege University, 1 Quai Roosevelt, 4000 TraceolabLiege, Belgium \\ ${ }^{3}$ School of Anthropology, University of Arizona, Tucson, AZ 85721-0030, USA
}

KEYWORDS: Bone retouchers - Retoucher grip • Neanderthals • Morphology • Fine motor skills • Chagyrskaya Cave

\section{ABStract}

When studying bone retouchers, researchers pay close attention to the morphological characteristics of the tool's active zone, and the lithic raw material processed. In our research, we found that the orientation of the bone retoucher in the hand and the grip employed to retain and manipulate it are crucial factors that affect the morphological characteristics of the retoucher's active zone. By examining two alternative grips for manipulating bone retouchers ((1) Using all the fingers of one hand in a power grip; (2) Using only the first three digits of one hand in a pinch grip), we found that when the retoucher is held in the first manner, the active area is larger, as is the amount of bone removed by the retoucher. When the retoucher was pinched with only three fingers in a precision grip, retouch damage was more densely concentrated and less bone was removed. The orientation of the retoucher in the hand and the grip employed have a greater influence on the active area than the extent of retoucher use, which we assessed by measuring the number of stone tool edges processed. By gripping the retoucher with all the fingers of one hand, the knapper automatically applies greater force, which results in the removal of more bone. Comparison of experimental bone retouchers with those recovered from Middle Paleolithic archaeological contexts in Cha- gyrskaya Cave (Altai, Russia) revealed that Altai Neanderthals practiced two methods of grasping bone retouchers, with a three-finger pinch grip being dominant. 


\section{Introduction}

Research on bone tools from the Lower, Middle and Upper Paleolithic has increased significantly in recent decades, as bone tool manufacture is directly linked to the cognitive and behavioral patterns of human ancestors (Soressi et al. 2013; Doyon et al. 2018; Mateo-Lomba et al. 2020; Vetese et al. 2020). Retouchers, employed in the fabrication and maintenance of stone tools comprise the most numerous category of bone tools ${ }^{1}$ throughout the Paleolithic.

The abundance of retouchers made on bones, mostly limb bone diaphyses, in Middle and Upper Paleolithic complexes facilitates their morphological and statistical studies. Several roughly similar approaches to the analysis of bone retouchers take into account the orientation of use-wear traces on active areas of the tool, the morphology of the traces (pits and furrows), their location on the retoucher, their metric parameters, and the degree of wear visible on the tool (Rigaud 1977; Veselsky 2008; Mallye et al. 2012; Mozota 2013, 2018). As a result, retouchers can be classified into distinct morphological categories.

A zooarchaeological approach to the study of bone retouchers provides information on economic models, hunting strategies of ancient human populations and their choice of retoucher blanks in anatomical context (Armand and Delagnes 1998; Costamagno et al. 2018).

Experiments are an important source of data for studying bone retouchers. Experimental approaches typically consider the condition of the bone (fresh or dry) on which the retoucher was made (Villa and Mahieu 1991; Tartar 2002; Karr and Outram 2012), whether the periosteum was removed and, if so, how often (Vincent 1993; Tartar 2009), methods of splitting bones to produce blanks for retouchers (Mozota 2013), retouching methods (percussion or pressure) and even the left-right laterality of use-wear traces on retouchers (Semenov 1957).

Here, we propose a new approach for examining the ways bone retouchers were gripped in the hand when retouching stone tools. As we will demonstrate, grip has a crucial impact on the morphological appearance of bone retouchers. The experiments we conducted highlighted two possible ways of manipulating bone retouchers: 1 . Using all the fingers of one hand in a power grip (Fig. 1, B); 2. Using only the first three digits of one hand - thumb, index, and middle fingers - to create a more precise grip (Fig. 1, A). Here, we attempt to determine how the easternmost Neanderthals gripped and manipulated bone retouchers based upon experimental evidence and archaeological data from Chagyrskaya Cave.

${ }^{1}$ Following Turner et al. (2020), "bone tools" refers to retouchers and other artifacts made of vertebrate hard tissues such as bone, as well as teeth, antler and ivory. 
Figure 1. Two ways of gripping bone retouchers: $A$. With only three digits (thumb, index finger, and middle finger) in a precision pinch grip; $B$. With all five fingers of one hand in a modified power grip.

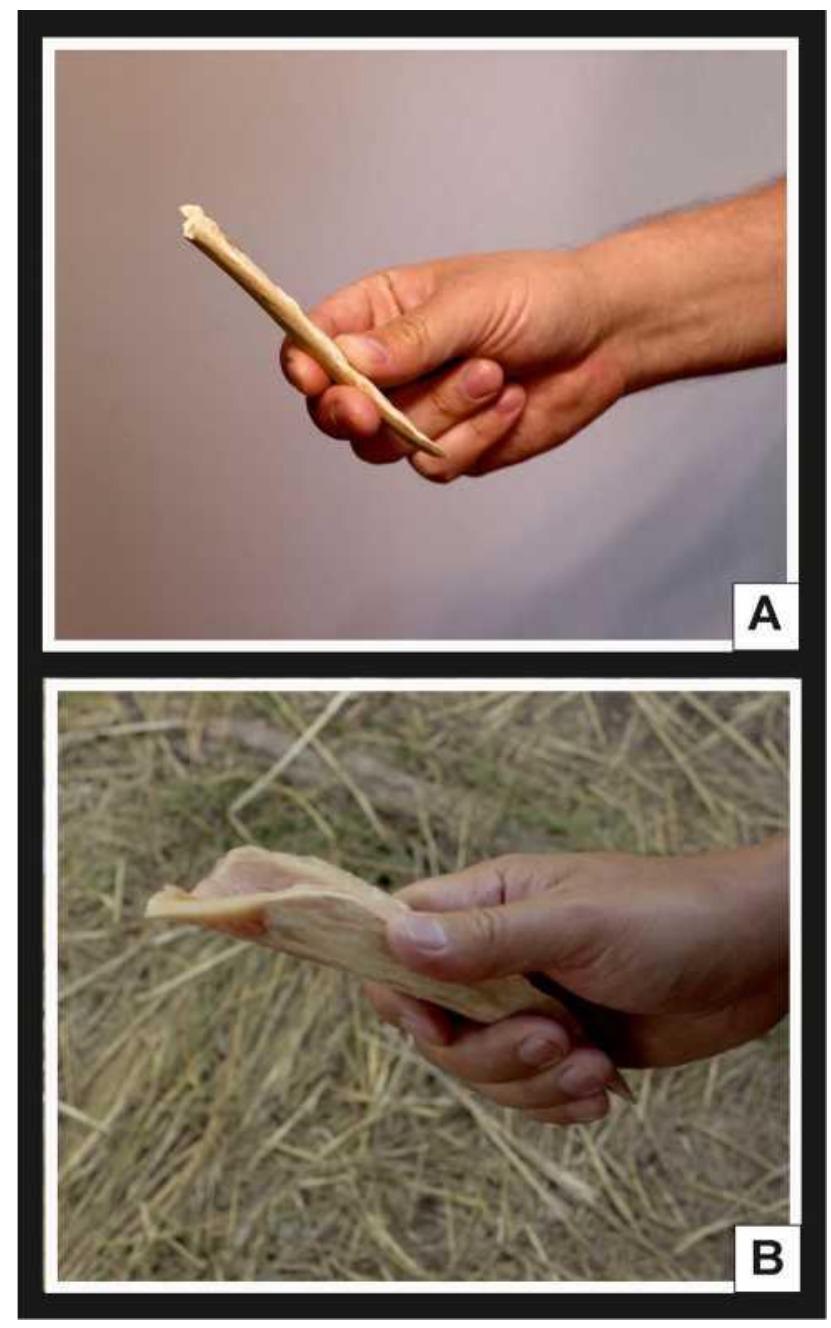

\section{Site description}

Chagyrskaya Cave is located in the foothills of the Altai Mountains, on the left bank of the Charysh River in southern Siberia, Russia (Fig. 2). The European Neanderthals who occupied the cave from ca. 60-50 kyr BP migrated there from Central and Eastern Europe, bringing with them Micoquian/KMG technology and the typological composition of the cave's lithic and bone assemblages (Kolobova et al. 2020b; Vernot et al. 2021).

Archaeologists interpret Chagyrskaya Cave as a residential base camp where prey species, principally Bison priscus and Equus (Sussemionus) ovodovi, were consumed by the cave's Neanderthal occupants (Kolobova et al. 2019a; Salazar-Garc^a et al. 2021). Hunting took place in the late summer and early autumn, when herds of bison, including males, females and immature individuals, migrated from the Altai plain to the foothills. Based on paleontological data, Neanderthals selected female and immature bison as their preferred prey (Kolobova et al. 2019a). 
A complex record of Neanderthal activity is preserved inside the cave, including a nearly complete sequence of lithic knapping, minus the core decortication stage, which apparently took place offsite. The abundant tool kit (comprising $25 \%$ of the lithic assemblage) is dominated by trapezoidal and leaf-shaped scrapers, simple scrapers, retouched points and truncated-faceted tools (Shalagina et al. 2015; Kolobova et al. 2019b, 2019a). A complete processing sequence of bone tools has also been recorded (Baumann et al. 2020).

The significant role played by retouching processes in Neanderthal knapping activity is indicated by $6.5 \%$ bifacial thinning flakes among blanks and $17 \%$ bifacial thinning chips among definable chips. In addition, the significant role of retouching and bifacial production at Chagyrskaya is evidenced by the largest collection of bone retouchers in northern Eurasia (Baumann et al. 2020; Kolobova et al. 2020a, c).

Approximately 1200 retouchers made on long bones, ribs and vertebrae of adult large herbivores have been recovered in the Chagyrskaya Cave complex (Fig. 4). The selectivity of the blanks, or their preparation, was so thorough that the anatomical shape of the bone blank had no discernable influence on the final shape of the retouchers, suggesting considerable deliberate modification of bone blanks (Kolobova et al. 2020a).

Our experimental data on local lithic raw materials indicate that bone retouchers were used during the final stage of bifacial production and for retouching numerous bifacial scrapers, resulting in large quantities of bifacial thinning flakes (Shalagina et al. 2020).

With respect to the manipulation of these bone retouchers, it is likely Chagyrskaya Neanderthals employed some combination of two approaches: gripping with all five fingers of one hand and grasping with the first three digits (thumb, forefinger, and middle finger) of only one hand. We found these two modes of gripping retouchers to be the most convenient. The difference between these approaches is that when one grasps the retoucher with three fingers, only the hand and wrist are involved in striking, limiting impact force. When gripping with all fingers, the hand and forearm are used to apply the force impulse, which allows strikes greater force. Other options for gripping retouchers can be considered: Mallye and colleagues state, "One of the experimenters held the retoucher pinched between the index and third finger, with the middle finger lodged in the medullar cavity of the bone; the other experimenter held the retoucher in the palm of the hand" (Mallye et al. 2012, 1133-1134). However, all means of gripping retouchers result in described force impulses. 
Figure 2. Map showing the location of Chagyrskaya Cave

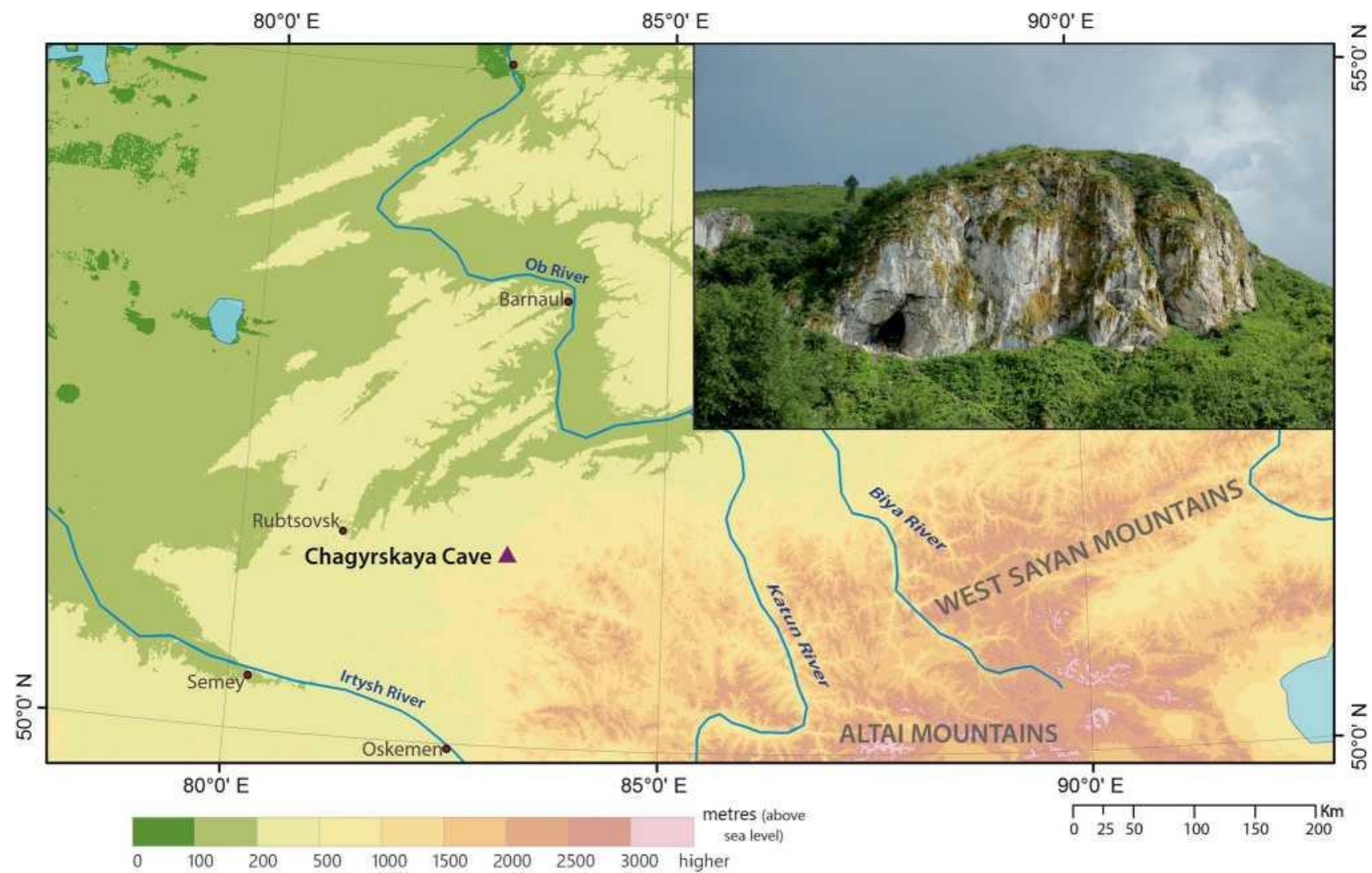

\section{Materials and methods}

Our co-author, V. Kharevich, an experienced archaeological experimenter and highly-skilled stone knapper, produced 38 bone retouchers from the long bones of cattle (Bos taurus, 33 specimens) and horse (Equus caballus, 5 specimens). The methods of producing retoucher blanks correspond to procedures employed for splitting large mammal bones published by Mozota (2013): 1. Striking the center of the bone - generally a limb bone diaphysis - with a stone hammer (17 items); 2 . Removal of epiphyses with a hammer and splitting the diaphysis into blanks (16 items); 3 . Direct strikes of the bone on a fixed stone anvil ( 5 items). According to our observations, all methods produce bone fragments suitable for further modification and use as retouchers. However, the first two approaches are the most productive. Subsequently, such retouchers were used to modify stone tools made from the local raw materials that Neanderthals exploited at Cha- gyrskaya Cave (e.g., jasperoids, chalcedonites, and various effusives).

With respect to the manipulation of these bone retouchers, it is likely Chagyrskaya Neanderthals employed some combination of two approaches:

1. Gripping with all five fingers of one hand $(n=15)($ Fig. 3, A); 
2. Grasping with the first three digits (thumb, forefinger, and middle finger) of only one hand $(n=23)$ (Fig. 3, B).

In the process of using these experimental retouchers, we recorded three conditional, relative degrees of utilization, assuming this variable may have had a significant influence on the shape and size of the retouchers' working area:

1. Retouching a single edge of a stone tool = weak degree of utilization $(n=17)$;

2. Retouching two edges of a stone tool = medium degree of utilization $(n=13)$;

3. Retouching three or more edges of a stone tool $=$ strong degree of utilization $(n=8)$.

All experimental and archaeological retouchers were scanned with a RangeVision $5 \mathrm{M}$ structured light scanner with a resolution of $0.4 \mathrm{~mm}$, following Kolobova et al. (2019c). The retouchers' active area was measured on the resulting three-dimensional models of both experimental and archaeological pieces by manually outlining the active area and measuring it in 3D Systems' Geomagic Wrap software (trial version) (Fig. 4, 1).

We calculated the volume of bone removed during the retouching process based upon our measurements of the tools' active area. To do this, we first determined the volume of the experimental retoucher. We then filled in a threedimensional model of the retoucher (using 3D Systems' Geomagic Wrap), reconstructing the tool to its unused state, and measured the volume. The difference between the volume of the reconstructed and the used retoucher defines the volume of bone lost from the retoucher during use (Fig. 4, 2).

In cases where a crack was noted on the retoucher that was not in contact with the active area of the retoucher, we ignored it, because it has no effect on the calculation of the active area or the volume of the removed bone. If the crack crossed the active zone of the retoucher, we filled it before making subsequent calculations. We filled cracks in the active zone of the retoucher following the relief of the active zone (Fig. 4, 1-3).

We compared the experimental (Fig. 3) and archaeological (Fig. 5) specimens statistically. In comparing the two samples, we used the t-test if the samples showed a normal distribution by the Shapiro-Wilk test. If the samples were not normally distributed, the Mann-Whitney test was employed. To compare multiple samples, we applied the non-parametric Kruskal-Wallis test when the samples were not normally distributed, or comprised a small sample size. The PERMANOVA non-parametric test (Hammer et al. 2001) was used to compare samples of the two variables simultaneously. 
Figure 3. Experimental retouchers gripped in two ways: $a$-With all five digits of one hand; $b$-With only three fingers (first, index, and middle)

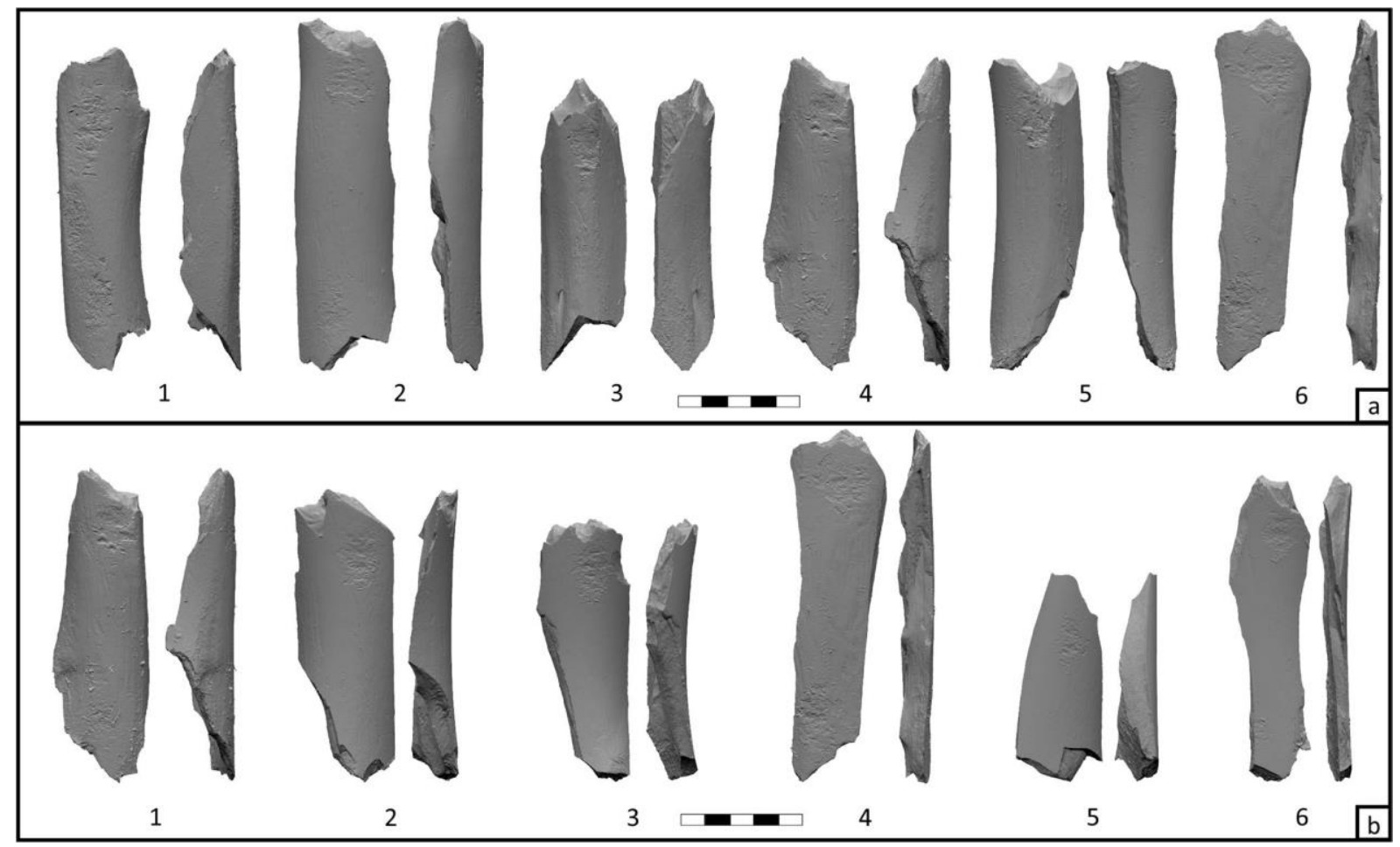

Figure 4. Measurement of values of main variables for the study of bone retouchers: 1-Determination of the active area; 2-Filling-in cracks crossing the active area; 3 - Filling-in the active area on the 3D model, to determine the initial volume of the retoucher blank.
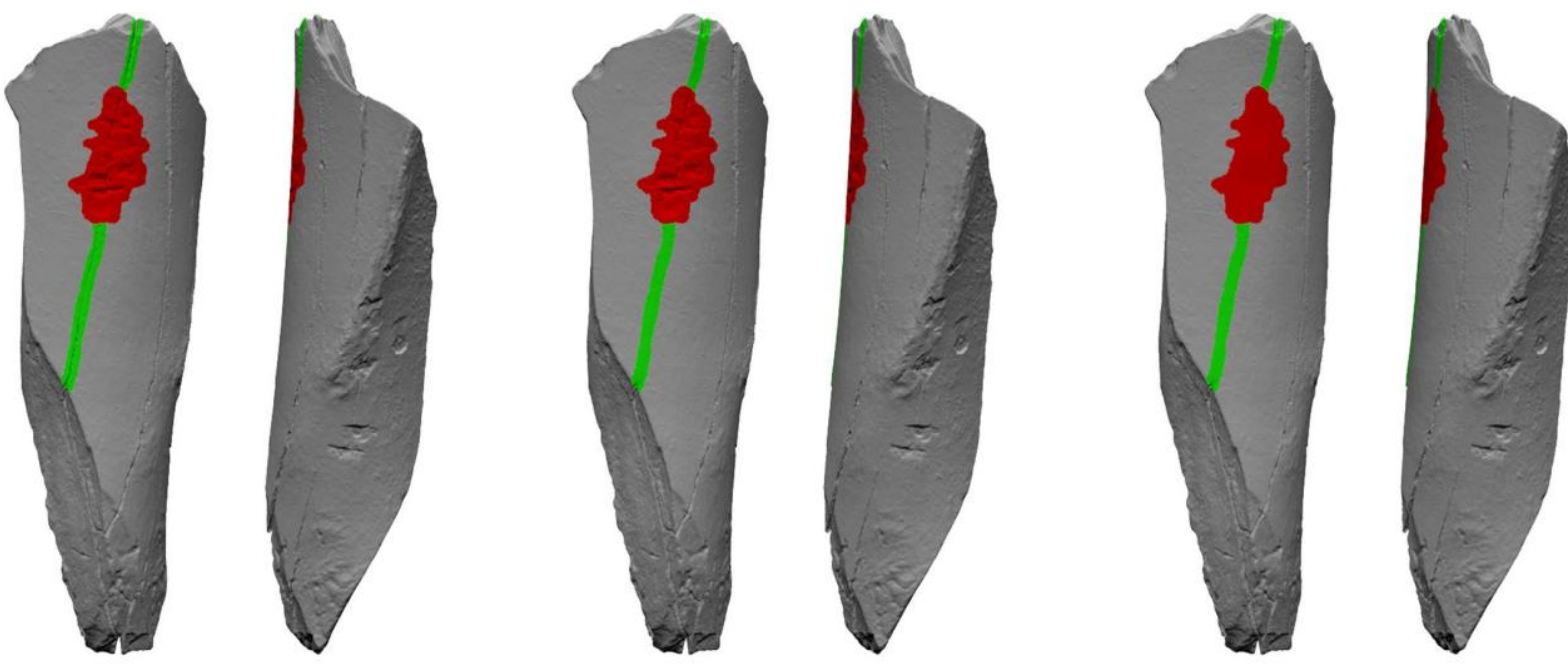

1

2 
Figure 5. The active areas of experimental retouchers depending on: $A$. the way the retoucher is held; $B$. the degree of retoucher utilization.

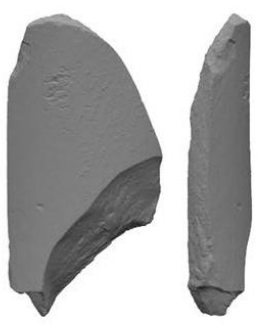

1

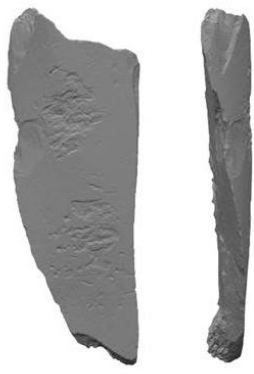

5
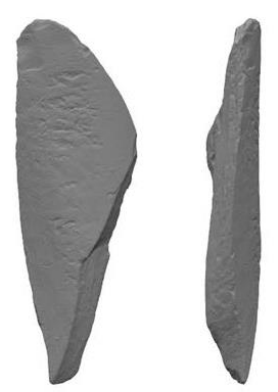

2

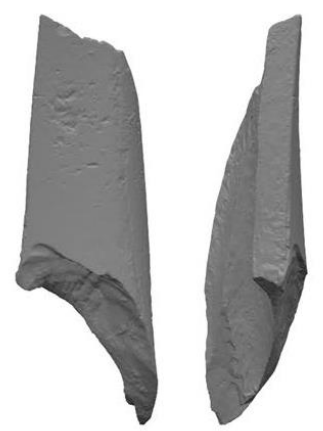

6

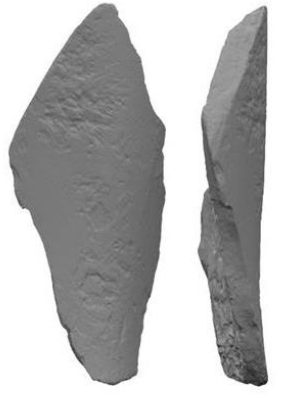

3

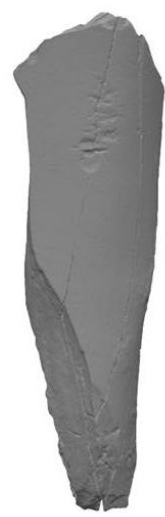

7

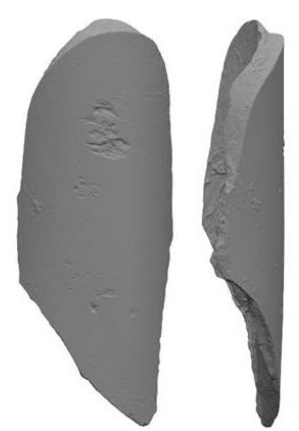

4

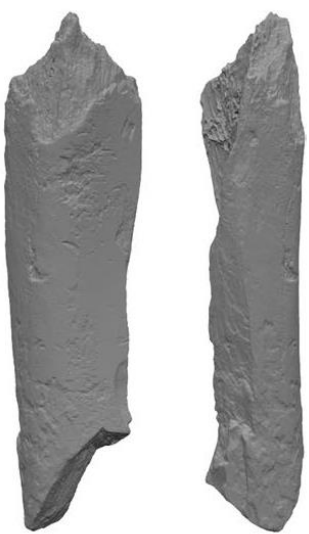

8

Figure 6. Bone retouchers from Chagyrskaya Cave, Altai Mountains, Russia.
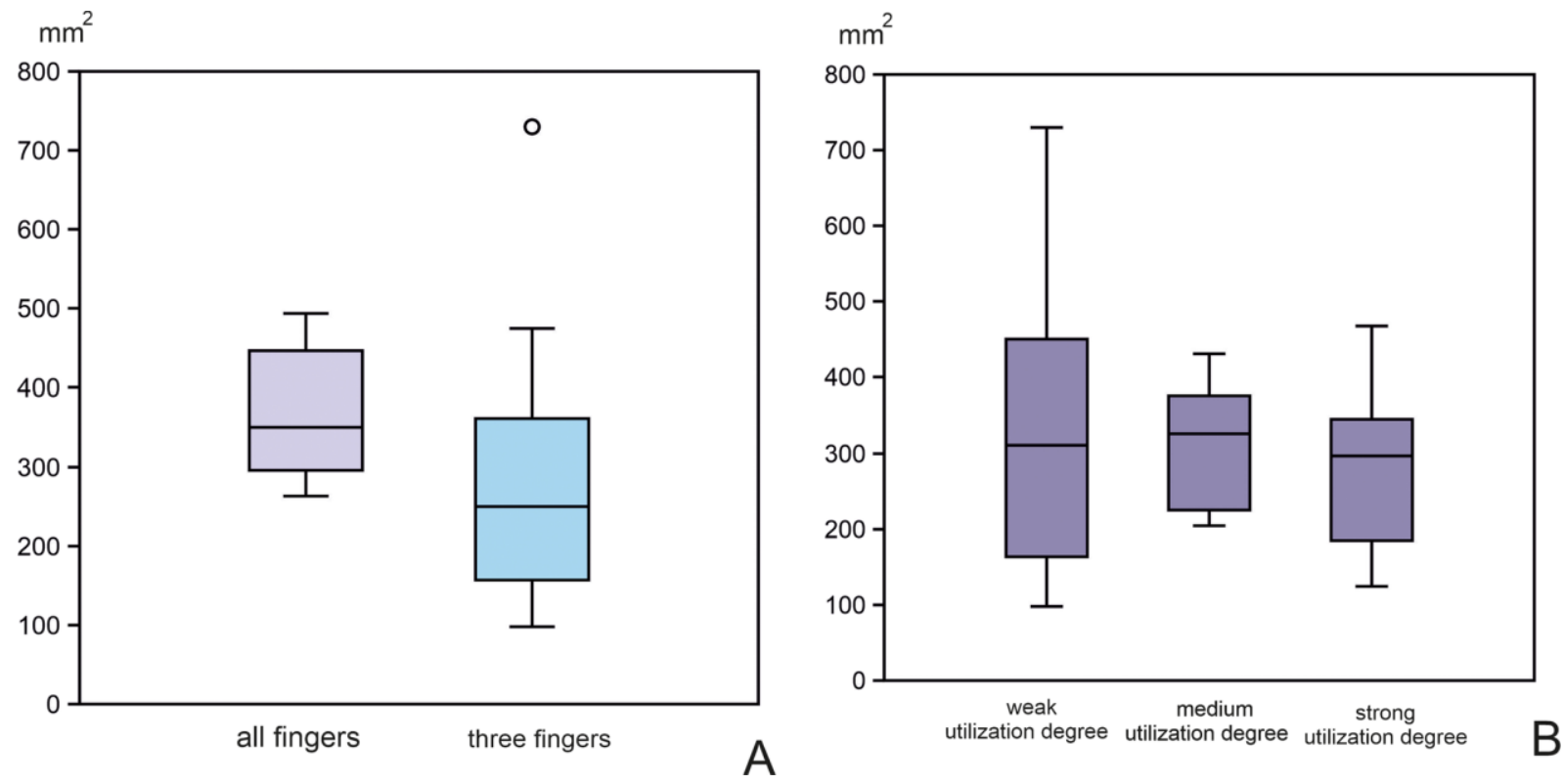


\section{Results}

According to our empirical observations, the way in which a retoucher is gripped effects the size and morphology of the retoucher's active area. To test this hypothesis, we compared the active areas of experimental retouchers (Fig. 6, A). When the retoucher is held with the whole hand, a larger working area is formed on the retoucher than when it is pinched with only three fingers. A ttest revealed a significant statistical difference between retouchers gripped in different ways $(t=$ $3.307, p=0.0044)$.

However, the active area can also be influenced by the intensity of the tool's use, so we compared the active areas of retouchers using this attribute (Fig. 6, B). We found that the number of stone edges processed by the retoucher has no significant effect on the area of active retoucher zones. This was confirmed by the non-parametric Kruskal-Wallis test for several samples, which showed no statistical difference between samples $\left(H\left(\chi^{2}\right)=0.8428 ; p=0.6561\right)$.

The next variable hypothesized to be influenced by the intensity of retoucher use is the amount of bone removed from the active area. We compared this variable on our experimental retouchers (Fig. 7, B) and discovered that, although we observed that slightly more bone was removed from the most intensively used retouchers, the Kruskal-Wallis test for equal medians revealed no significant statistical difference $\left(H\left(\chi^{2}\right)=1.115 ; p=0.5727\right)$.

In contrast to this observation, the manner in which retouchers are gripped has a statistically significant effect on the amount of bone removed (Fig. 7, A). We compared the two samples by applying a non-parametric Mann-Whitney test for equal medians (Mann-Whitney $U=99 ; p=0.038$ ) and obtained a significant statistical difference between retouchers held in varying ways. Even when the amount of bone removed from retouchers gripped in the same manner is measured, no statistically significant difference was noted.

In order to compare our experimental results with archaeological retouchers from Chagyrskaya Cave, we plotted the active area of the tools and the bone volume removed from them (Fig. 8). We found that many of the archaeological retouchers fell within the distribution of experimental counterparts that were manipulated with a more precise three- finger pinch grip. Nevertheless, a certain proportion of archaeological retouchers may have been gripped with all of the fingers of one hand, especially in the plot distribution area where the experimental retouchers' data overlap. Several archaeological retouchers were apparently manipulated with all the fingers of one hand in a modified power grip.

We applied a non-parametric PERMANOVA test in order to determine which experimental retouchers correspond best to the archaeological collection. We observed a statistically significant difference $(F=9.163 ; p=0.0003$ ) between the three samples (i.e., retouchers gripped by all five digits of one hand, those manipulated in a three-finger precision grip, and archaeological retouchers). A pairwise comparison of samples revealed that the Chagyrskaya archaeological collection differed significantly from the experimental tools gripped with all the fingers of one hand $(F=16.21 ; p=0.0001)$ and not significantly from retouchers manipulated in a three-finger grip $(F=$ 
$0.1711 ; p=0.71)$. Based upon our hypothesis that the choice of retoucher grip-type is influenced by the size of the bone blank, we discovered that among experimental pieces, the longer the retoucher, the more likely the knapper was to choose it for gripping with all five digits of the hand. Among archaeological retouchers, however, no such correlation was found: the active area of the tool was insignificantly positively correlated with its length (Spearman correlation coefficient $=$ 0.4225).

Figure 7. Volume of bone material removed depending upon: $A$. the way in which the retoucher is gripped; $B$. the degree of retoucher utilization.
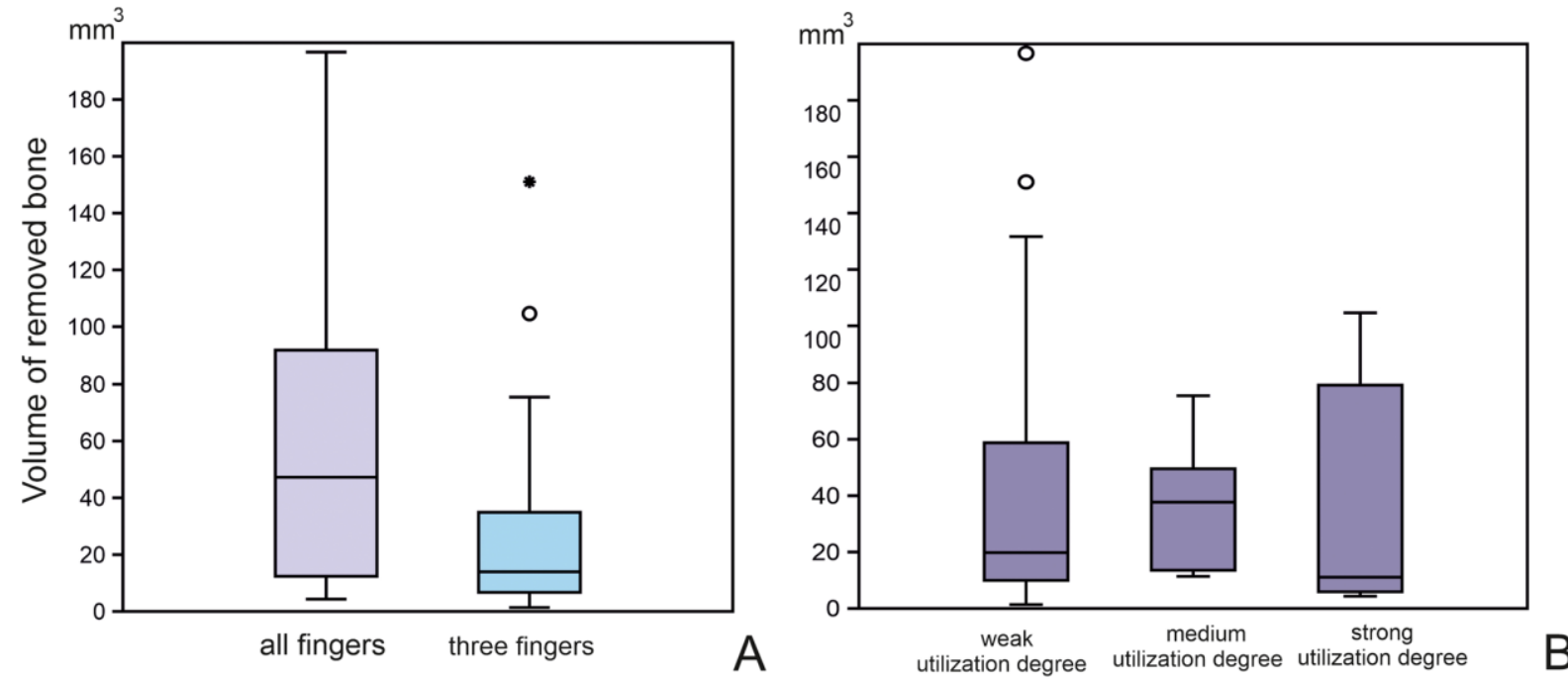

Figure 8. Correlation between the area of the active zone and the volume of bone removed on experimental and archaeological retouchers from Chagyrskaya Cave, Russia.

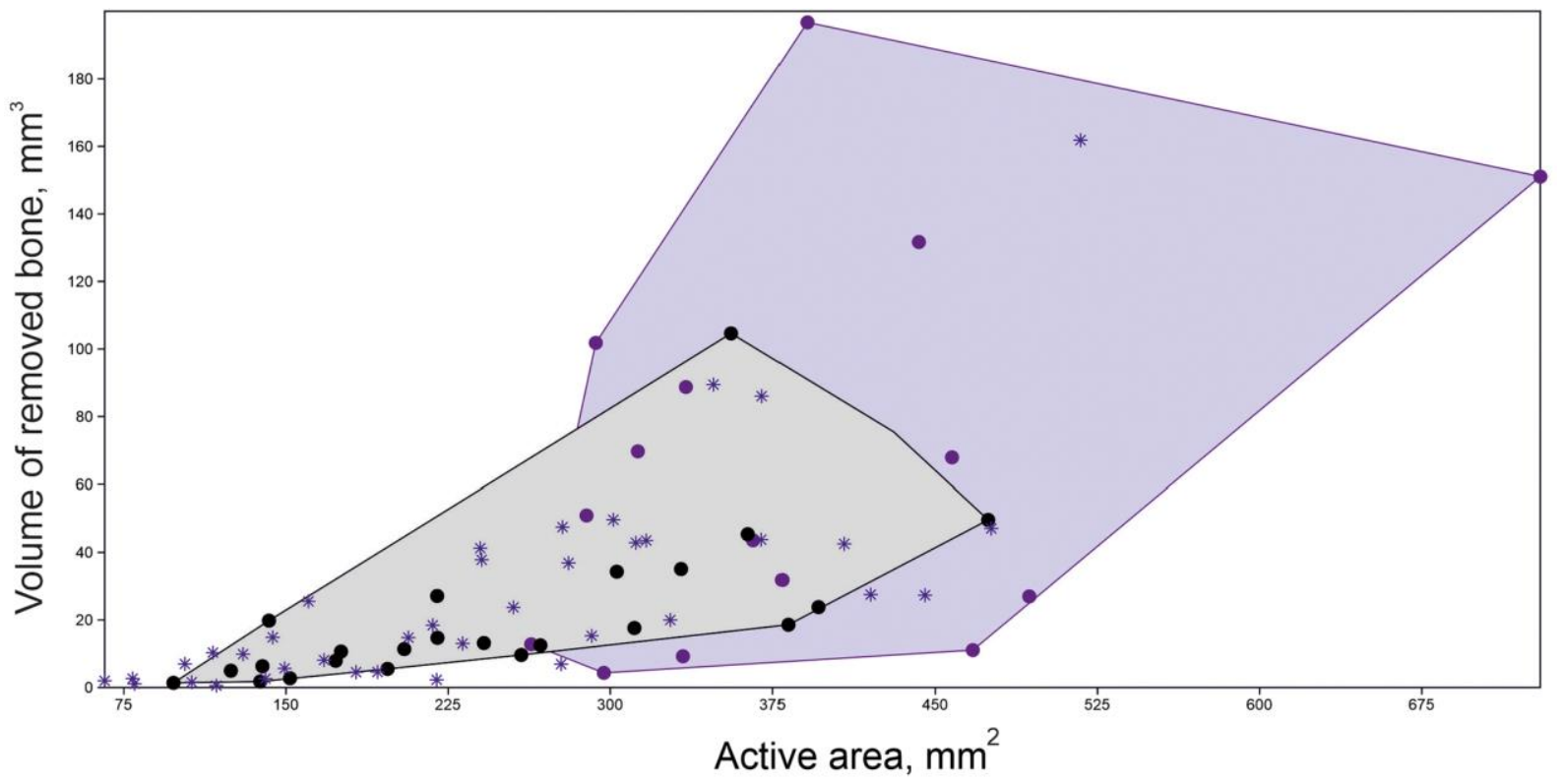

Experimental retouchers held with all the fingers of one hand

Experimental retouchers held with two fingers of one hand * Archaeological retouchers 


\section{Discussion and conclusion}

Our research demonstrates that the way in which bone retouchers are gripped during use (i.e., with all five digits of one hand or with only the first three fingers) has a significant impact on the morphological appearance of such tools. The way the retoucher is gripped has a more significant influence on active area morphology than the degree of retoucher utilization (measured in terms of the number of stone tool edges processed).

By identifying the values of two variables (the active area of the retoucher and the amount of bone material removed), it is possible to reconstruct the way in which the tool was gripped. The simplicity of this approach for determining retoucher grip technique makes it easily applicable to the study of bone (and possibly stone) retouchers from other archaeological contexts.

Even experienced stone knappers involuntarily or accidentally apply greater force when gripping the retoucher with all their fingers than when manipulating the retoucher with only three digits, resulting in the removal of a greater volume of bone material. The fact that the number of stone tool edges processed has no significant effect on the amount of bone material removed suggests that the force applied has a greater effect on the final morphological appearance of the retoucher than the number of edges processed by that tool and, therefore, the amount of time the retoucher was used.

We found that the Neanderthal residents of Chagyrskaya Cave manipulated retouchers with a three-finger pinch grip in most cases. This preferential grip technique indicates a significant level of fine motor skills and substantial control of the retouching process. These results are consistent with published data on the anatomical structure of the Neanderthal hand and their undoubted ability to perform fine motor activities (Niewoehner et al. 2003; Bardo et al. 2020). However, this pattern is not true of all Chagyrskaya Cave archaeological retouchers, since several tools exhibit characteristics typical of retouchers manipulated by all the digits of one hand in a power grip. It is likely that we are witnessing evidence of a complex activity undertaken by Neanderthals in which they preferentially changed retoucher grip-type from precision to power to perform tasks requiring the application of significant force (e.g., re-shaping a scraper or biface or other actions requiring the removal of a substantial amount of lithic material).

One possible explanation for observed variability in retoucher grip-types may relate to different functional purposes. When making a stone tool, a series of operations with changing angles and directions of chipping and retouching are required (e.g., when trimming the point of a bifacial tool). To efficiently accomplish such a task, it would be preferable to grip the retoucher with all the fingers of one hand, allowing more flexibility variability in its manipulation. As a result, the active area is larger than that of retouchers held with just three fingers. On the other hand, retouching or rejuvenation operations require retoucher blows directed at a particular angle and in a single direction, which is easier to accomplish by gripping the retoucher with three fingers. This grip technique also reduces the risk of excessively strong impact that might break the tool. 
In order to test this hypothesis, we compared the relative position of linear traces on the active areas of experimental retouchers gripped with all five fingers (Fig. 9, 1) and with only three digits (Fig. 9, 3). We also compared active areas on experimental retouchers with their archaeological counterparts which corresponded in size of the active areas and bone removed to the two grip techniques described above (Fig. 9, 2, 4). Based on our observations, this hypothesis is reasonable, because linear traces on experimental and archaeological retouchers manipulated with all five fingers of one hand (Fig. 9, 1,2) are less parallel than similar linear traces found on retouchers held with three digits in a pinch grip (Fig. 9, 3, 4). Nevertheless, additional directed studies are required for final validation.

The predominance in the archaeological assemblage of retouchers gripped by only three fingers may indicate an emphasis on stone tool rejuvenation over tool production. This supposition is indirectly confirmed by the significant number of bifacial thinning flakes and chips in the Chagyrskaya Cave lithic assemblage. This is in accordance with data from the attribute analysis of the lithic assemblage which contains $6.5 \%$ bifacial thinning flakes (of all flakes) and $17 \%$ bifacial thinning chips (of all chips). The characteristics of the proximal zones of these flakes and chips are associated with the use of a soft hammer (absent diffused bulb of percussion combined with a lip). The only possible soft hammers in the Chagyrskaya complex are bone retouchers. Taking into account the fact that typologically recognizable bifacial thinning flakes and chips were produced only at the final stages of the production of plano-convex bifaces or scrapers, we noted only a small portion of the flakes produced by bone retouchers. This is supported by the fact that about one-third of the blanks in the Chagyrskaya Cave collections have characteristics associating them with soft hammer production. Thus, we conclude that bone retouchers were actively used by the Chagyrskaya Cave Neanderthals to rejuvenate and produce stone tools (Kolobova et al. 2019b; Shalagina et al. 2019).

Despite numerous studies of Neanderthal behavior, our knowledge of this ancestral human subspecies is still very limited. These new data from Chagyrskaya Cave comprisevaluable pieces of a very complex puzzle of Neanderthal behavioral abilities that is now beginning to slowly emerge. 
Figure 9. Determining the angles of linear traces on experimental $(1,3)$ and archaeological $(2,4)$ bone retouchers: 1-2. Experimental and archaeological retouchers gripped with all five digits of one hand; 3-4. Experimental and archaeological retouchers manipulated with only three fingers.

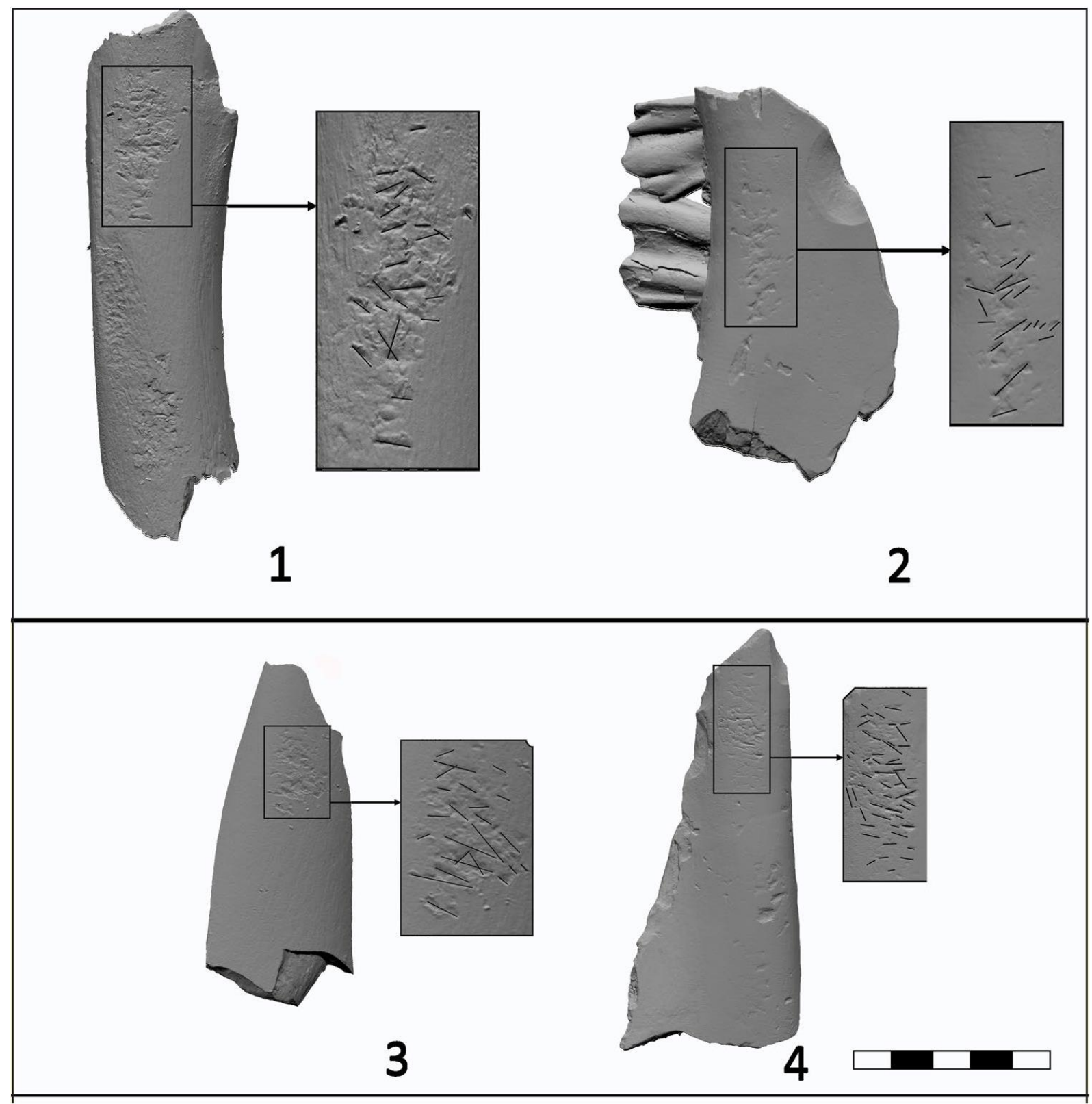

SUPPLEMENTARY INFORMATION The online version contains supplementary material available at https://doi.org/10.1007/s12520-021-01495-x.

ACKNOWLEDGEMENTS This study was generously supported by a Russian Science Foundation grant (\# 21-18-00376). Olsen's participation was facilitated by the University of Arizona's Je Tsongkhapa Endowment for Central and Inner Asian Archaeology. Baumann's participation was supported by a Marie Sklodowska-Curie Actions postdoctoral fellowship (\#839528). The authors are grateful to the anonymous reviewers of our draft manuscript for their helpful comments and suggestions.

The authors have no competing interests to declare. This study did not involve any underlying data. 


\section{References}

Armand D, Delagnes A (1998) Les retouchoirs en os d'Artenac (couche 6c): perspectives archéozoologiques, taphonomiques et expérimentales. In: Jean-Philip, B.., Liliane, M., Patou-Mathis, M. (Eds.), Les Comportements de Subsistance Au Paleo- Lithique, XviieRencontres Internationales d'Archeologie et d'Histoired'Antibes. Sophia Antipolis, pp. 205-214

Bardo A, Moncel MH, Dunmore CJ, Kivell TL, Pouydebat E, Cornette R (2020) The implications of thumb movements for Neanderthal and modern human manipulation. Sci Rep 10:1-12. https://doi.org/10.1038/s41598-020-75694-2

Baumann M, Plisson H, Rendu W, Maury S, Kolobova K, Kriv- oshapkin A (2020) The Neandertal bone industry at Chagyrs- kaya cave, Altai Region, Russia. Quatern Int 559:68-88. https:// doi.org/10.1016/j.quaint.2020.06.019

Costamagno S, Bourguignon L, Soulier M-C, Meignen L, Beauva C, Rendu W, Mussini C, Mann A, Maureille B (2018) Bone retouchers and site function in the Quina Mousterian: The case of Les Pradelles (Marillac-Le-France, France). In: Hutson, J.., Garc^a-Moreno, A., Noack, E.S., Turner, E., Villaluenga, A., Gaudzinski-Windheuser, S. (Eds.), Origins of Bone Tool Technologies. Mainz, pp. 165-196

Doyon L, Li Z, Li H, d'Errico F (2018) Discovery of circa 115,000-year-old bone retouchers at Lingjing, Henan, China. PLoS ONE 13:1-16. https://doi.org/10.1371/journal.pone. 0194318

Hammer 0, Harper DAT, Ryan PD (2001) Past: paleontological statistics software package for education and data analysis. Palae- ontol Electron 4:1-9

Karr LP, Outram AK (2012) Tracking changes in bone fracture morphology over time: environment, taphonomy, and the archaeological record. J Archaeol Sci 39:555-559. https://doi.org/10. 1016/j.jas.2011.10.016

Kolobova K, Chabai V, Krajcarz M, Krajcarz M, Shalagina A, Rendu W, Vasiliev SV, Markin SV, Krivoshapkin Al (2019a) Exploitation of the natural environment by Neanderthals from Chagyrskaya Cave ( Altai ). Quartar 66:7-31. https://doi.org/10.7485/QU66

Kolobova K, Shalagina A, Chabai V, Markin S, Krivoshapkin A (2019b) Signification des technologies bifaciales au Paléolithique moyen des montagnes de l'Altaï. L'anthropologie 123. https://doi. org/10.1016/j.anthro.2019.06.004

Kolobova K, Fedorchenko A, Basova N, Postnov AV, Kovalev V, Chistyakov P, Molodin V (2019c) The Use of 3D-Modeling for Reconstructing the Appearance and Function of Non-Utilitarian Items (the Case of Anthropomorphic Figurines from Tourist-2). Archaeol Ethnol Anthropol Eurasia 47:66-76. https://doi.org/10. 17746/1563-0110.2019.47.4.066-076

Kolobova K, Rendu W, Shalagina A, Chistyakov P, Kovalev V, Baumann M, Koliasnikova A, Krivoshapkin A (2020a) The application of geometric-morphometric shape analysis to Middle Paleolithic bone retouchers from the Altai Mountains, Russia. Quatern Int 559:89-96. https://doi.org/10.1016/j.quaint.2020.06.018

Kolobova KA, Roberts RG, Chabai VP, Jacobs Z, Krajcarz MT, Shala- gina AV, Krivoshapkin AI, Li B, Uthmeier T, Markin SV, Morley MW, O'Gorman K, Rudaya NA, Talamo S, Viola B, Derevianko AP (2020b) Archaeological evidence for two separate dispersals of Neanderthals into southern Siberia. Proc Natl Acad Sci USA 117:2879-2885. https://doi.org/10.1073/pnas.1918047117 
Kolobova KA, Kolyasnikova AS, Chabai VP, Chistyakov PV, Baumann M, Markin SV, Krivoshapkin AI (2020c) Middle paleolithic bone retouchers: Size or proportions. Archaeol Ethnol Anthropol Eurasia 48:14-26. https://doi.org/10.17746/1563-0110.2020.48.4. 014-026

Mallye JB, Thiébaut C, Mourre V, Costamagno S, Claud É, Weis- becker P (2012) The Mousterian bone retouchers of Noisetier Cave: Experimentation and identification of marks. J Archaeol Sci 39:1131-1142. https://doi.org/10.1016/j.jas.2011.12.018

Mateo-Lomba P, Fernández-Marchena JL, Ollé A, Caceres I (2020) Knapped bones used as tools: experimental approach on different activities. Quatern Int 569-570:51-65. https://doi.org/10.1016/j. quaint.2020.04.033

Mozota M (2013) An experimental programme for the collection and use of retouching tools made on diaphyseal bone splinters. EXARC J 2

Mozota M (2018) Experimental programmes with retouchers: where do we stand and where do we go now? In: Hutson, J.., Garc^a- Moreno, A., Noack, E.S., Turner, E., Villaluenga, A., Gaudzinski- Windheuser, S. (Eds.), The Origins of Bone Tool Technologies. Mainz, pp. 15-32

Niewoehner WA, Bergstrom A, Eichele D, Zuroff M, Clark JT (2003) Manual dexterity in Neanderthals. Nature 422:395. https://doi. org/10.1038/422395a

Rigaud A (1977) Analyse typologique et technologique des grattoirs magdaléniens de La Garenne à Saint-Marcel (Indre). Gallia Prehistoire 20:1-43

Salazar-García DC, Power RC, Rudaya N, Kolobova K, Markin S, Krivoshapkin A, Henry AG, Richards MP, Viola B (2021) Dietary evidence from Central Asian Neanderthals : a combined isotope and plant microremains approach at Chagyrskaya Cave, Altai. J Hum Evol 156:102985. https://doi.org/10.1016/j.jhevol.2021. 102985

Semenov SA (1957) Primitive Technique (Experience of the Study of Ancient Tools and Products by Traces of Work). Moscow, Leningrad, Publishing house of the USSR Academy of Sciences (In Russian)

Shalagina AV, Krivoshapkin Al, Kolobova KA (2015) Truncated-faceted pieces in the paleolithic of northern Asia. Archaeol Ethnol Anthropol Eurasia 43:33-45

Shalagina A, Kolobova K, Krivoshapkin A (2019) Scar pattern analysis as a method for the reconstruction of lithic artifacts production sequence. Stratum plus 2019:145-154

Shalagina AV, Kharevich V, Baumann M, Kolobova KA (2020) Reconstruction of the bifacial technological sequence in Chagyrskaya Cave assemblage. Siber Hist Res 3:130-151. https://doi.org/10. $17223 / 2312461 X / 29 / 9$

Soressi M, McPherron SP, Lenoir M, Dogandžić T, Goldberg P, Jacobs Z, Maigrot Y, Martisius NL, Miller CE, Rendu W, Richards M, Skinner MM, Steele TE, Talamo S, Texier JP (2013) Neandertals made the first specialized bone tools in Europe. Proc Natl Acad Sci USA 110:14186-14190. https://doi.org/10.1073/pnas.13027 30110

Tartar E (2002) Etude fonctionnelle d'os a impressions de Starosele et Kabazi V (Crimee, Ukraine)

Tartar E (2009) De l'os a l'outil : caracterisation technique, eco-nom- ique et sociale de l'utilisation de l'os a l'Aurignacien ancien.Etude de trois sites : l'Abri Castanet (secteurs nord et sud), Brassempouy (grotte des Hyènes et abri Dubalen) et Gatzarria. Thèse de doc- torat, universite Paris I, Pantheon-Sorbonne 
Vernot B, Zavala El, Gómez-Olivencia A, Jacobs Z, Slon V, Mafessoni F, Romagne F, Pearson A, Petr M, Sala N, Pablos A, Aranburu A, de Castro JMB, Carbonell E, Li B, Krajcarz MT, Krivoshap- kin Al, Kolobova KA, Kozlikin MB, Shunkov MV, Derevianko AP, Viola B, Grote S, Essel E, Herraez DL, Nagel S, Nickel B, Richter J, Schmidt A, Peter B, Kelso J, Roberts RG, Arsuaga J-L, Meyer M (2021) Unearthing Neanderthal population history using nuclear and mitochondrial DNA from cave sediments. Science 372:eabf1667. https://doi.org/10.1126/science.abf1667

Veselsky AP (2008) Kabazi V: Bone and Stone Tools Used in Flint Knapping. Kabazi V: Interstratification of Micoquian \& Levallois- Mousterian camp sites 427-453

Vettese D, Blasco R, Caceres I, Gaudzinski-Windheuser S, Moncel MH, Hohenstein UT, Daujeard C (2020) Towards an understanding of hominin marrow extraction strategies: a proposal for a percussion mark terminology. Archaeol Anthropol Sci 12. https://doi. org/10.1007/s12520-019-00972-8

Villa P, Mahieu E (1991) Breakage patterns of human long bones. J Hum Evol 21:27-48. https://doi.org/10.1016/0047-2484(91) 90034-S

Vincent A (1993) L'outillage osseux au Paleolithique moyen: une nouvelle approche. PhD thesis, University Paris X-Nanterre 